\title{
Metabolites from nematophagous fungi and nematicidal natural products from fungi as an alternative for biological control. Part I: metabolites from nematophagous ascomycetes
}

\author{
Thomas Degenkolb $^{1}$ • Andreas Vilcinskas ${ }^{1,2}$
}

Received: 4 October 2015 /Revised: 29 November 2015 / Accepted: 2 December 2015 / Published online: 29 December 2015

(C) The Author(s) 2015. This article is published with open access at Springerlink.com

\begin{abstract}
Plant-parasitic nematodes are estimated to cause global annual losses of more than US\$ 100 billion. The number of registered nematicides has declined substantially over the last 25 years due to concerns about their non-specific mechanisms of action and hence their potential toxicity and likelihood to cause environmental damage. Environmentally beneficial and inexpensive alternatives to chemicals, which do not affect vertebrates, crops, and other non-target organisms, are therefore urgently required. Nematophagous fungi are natural antagonists of nematode parasites, and these offer an ecophysiological source of novel biocontrol strategies. In this first section of a two-part review article, we discuss 83 nematicidal and non-nematicidal primary and secondary metabolites found in nematophagous ascomycetes. Some of these substances exhibit nematicidal activities, namely oligosporon, 4',5'-dihydrooligosporon, talathermophilins A and B, phomalactone, aurovertins $\mathrm{D}$ and $\mathrm{F}$, paeciloxazine, a pyridine carboxylic acid derivative, and leucinostatins. Blumenol A acts as a nematode attractant. Other substances, such as arthrosporols and paganins, play a decisive role in the life cycle of the producers, regulating the formation of reproductive or trapping organs. We conclude by considering the potential applications of these beneficial organisms in plant protection strategies.
\end{abstract}

Andreas Vilcinskas

Andreas.Vilcinskas@agrar.uni-giessen.de;

andreas.vilcinskas@agrar.uni-giessen.de

1 Institute for Insect Biotechnology, Justus-Liebig-University of Giessen, Heinrich-Buff-Ring 26-32, 35392 Giessen, Germany

2 Department of Bioresources, Fraunhofer Institute for Molecular Biology and Applied Ecology, Winchester Strasse 2,

35394 Giessen, Germany
Keywords Phytoparasitic nematodes · Nematicides · Oligosporon-type antibiotics $\cdot$ Nematophagous fungi . Secondary metabolites $\cdot$ Biocontrol

\section{Introduction}

\section{Nematodes as economically important crop pests}

Among more than 26,000 known species of nematodes, 8000 are parasites of vertebrates (Hugot et al. 2001), whereas 4100 are parasites of plants, mostly soil-borne root pathogens (Nicol et al. 2011). Approximately 100 species in this latter group are considered economically important phytoparasites of crops. Nematodes can damage all parts of their host plants, although according to their life style, individual species target the stems, leaves, flowers, or seeds. Root nematodes can be subdivided further into free-living ectoparasites, migratory species, and sedentary endoparasites (Dowe 1987). The latter group is responsible for most damage to crops (Jansson and López-Llorca 2004). It includes the root-knot nematodes (Meloidogyne spp.) and the cyst nematodes (Heterodera and Globodera spp.). A characteristic feature of most phytoparasitic nematodes is their protractible stylet, a spearshaped hollow feeding organ that is used to puncture cells.

Currently, the three most prevalent phytoparasitic nematodes in Europe are the beet cyst nematode Heterodera schachtii, the stem and bulb nematode Ditylenchus dipsaci, and the golden potato cyst nematode Globodera rostochiensis. The latter is a quarantine organism, which was the major potato crop pest until the 1980s when it was brought under control by the development of potato cultivars resistant to the nematode pathotype Ro1. Other invasive cyst nematodes pose a risk if accidentally introduced into Europe because they may outcompete the well-controlled incumbent species. For 
example, the white potato cyst nematode (Globodera pallida) would probably outcompete G. rostochiensis pathotype Ro1 after a number of rotations without targeted countermeasures (KWS Saat 2012). Among the 97 validly described Meloidogyne species (Hunt and Handoo 2009), the northern root-knot nematode (Meloidogyne hapla) is dominant in temperate regions, followed by Meloidogyne naasi and Meloidogyne chitwoodi, whereas in warmer climates and under glasshouse conditions, crops are predominantly infected with Meloidogyne fallax, Meloidogyne incognita, Meloidogyne arenaria, or Meloidogyne javanica (Wesemael et al. 2011).

Nematode damage in crops is non-specific and causes a range of symptoms from mild to severe, such as wilting, stunting, reduced vigor, nutrient deficiency, root lesions, reduced flowering, fruit loss, poor yield, and even death. Mild symptoms may be overlooked, and even the severe symptoms can be misdiagnosed (Nicol et al. 2011). Only few diagnostic symptoms are apparent. Above ground, these include small chlorotic or necrotic patches that spread rapidly from the site of infection. Below ground, they include root galls, cysts, and clumps of nematodes that are commonly described as "nematode wool." Worldwide annual yield losses caused by phytoparasitic nematodes are 3.3-20.6\%, averaging $12.3 \%$. Losses in the tropics and subtropics are generally higher than in temperate zones, and developing countries are more severely affected than industrialized countries. The global financial impact of phytoparasitic nematodes may be as high as US\$ 121 billion, including US\$ 9.1 billion in the USA (Chitwood 2003; Nicol et al. 2011).

\section{Chemical control of phytoparasitic nematodes}

Nematicidal chemicals for crop protection must be sufficiently volatile and water-soluble to ensure an even distribution in the upper soil layer without absorption to soil particles. This requires high doses during application, which contradicts groundwater protection policies. Even if these physical barriers are overcome, the chemical control of economically important cyst nematodes is remarkably inefficient because most nematicides cannot penetrate the proteinaceous matrix of the hardened cyst. Phytoparasitic nematodes reproduce at a prodigious rate, so the overall effectiveness of many classical nematicides is questionable.

Both registered and obsolete nematicides (including soil fumigants) applied in the USA have been comprehensively reviewed by Chitwood (2003). Many of the classical fumigant nematicides have been banned by the US Environmental Protection Agency (EPA) and/or the European Commission, and the number of non-fumigant nematicides in current use has declined over the last 25 years. In both cases, this reflects concerns about their non-specific mechanisms of action and therefore the potential negative impact on human health and the environment.

By 2015 , the broad-spectrum, systemic organothiophosphate fosthiazate (Nemathorin $10 \mathrm{G}^{\mathbb{B}}$ ) was the only nematicide still registered in Germany for the control of larval and adult stages of potato cyst nematodes (G. rostochiensis and G. pallida) in late season potato varieties. Root-knot nematodes (Meloidogyne spp.) as well as migratory endoparasitic root-lesion nematodes (Pratylenchus spp.) and stubby-root nematodes (Trichodorus spp.) may also be controlled by this chemical. This compound has several desirable side effects, including the reduction in damage to potato tubers caused by wireworms (Agriotes spp.), the larvae of click beetles (Coleoptera: Elateridae). In order to guarantee high levels of safety and efficacy, $3 \mathrm{~kg}$ of the active product per hectare $(=30 \mathrm{~kg}$ of granules) must be incorporated immediately and completely to a soil depth of $10-15 \mathrm{~cm}$ using a granule applicator. No spilled granules must remain on the soil surface because fosthiazate is toxic to birds and aquatic organisms (Börner 2009). The product is not registered in Austria or Switzerland because both countries still use the dithiocarbamate dazomet $\left(\right.$ Basamid $\left.^{\circledR}\right)$, which is hydrolyzed to produce hydrogen sulfide, formaldehyde, methylamine, and methyl isothiocyanate (MITC). The latter compound, which is regarded as the bioactive principle of the precursor dazomet, is nematicidal, insecticidal, herbicidal, and fungicidal. However, it is also toxic to fish and other aquatic organisms, and in humans, it is a lachrymator and a topical and respiratory irritant, eventually causing respiratory edema (EFSA 2010; Römpp 2015).

\section{Nematophagous fungi for the control of phytoparasitic nematodes}

Environmentally beneficial and low-cost alternatives to chemical control measures for phytoparasitic nematodes are needed, and these must not affect vertebrates, crops, and other nontarget organisms. Highly specific, preferably soil-borne antagonists are best suited for this purpose. Several entomopathogenic and fungicolous fungi have been registered for the biocontrol of insect pests and soil-borne plant pathogens in Austria, Switzerland, and Germany (AGES 2015; BLW 2015; BVL 2015); therefore, nematophagous fungi could fulfill an analogous role for the biocontrol of phytoparasitic nematodes. Approximately 700 species of nematophagous fungi have been described thus far (Yu et al. 2014), and four ecophysiological categories have been proposed (Yang and Zhang 2014), which are considered in turn below. However, taxonomic identification of the nematode species to be controlled is crucial to achieve a high level of control. In this context, it is important to consider that phytophagous nematodes carrying a stylet are unable to swallow fungal spores, whereas saprotrophic microbiophagous nematodes can take up spores orally (Dowe 1987). This distinction greatly affects the choice of the biocontrol agent to be applied. 
Nematode-trapping or predacious fungi form adhesive or mechanical hyphal traps. Earlier classifications based on morphological features such as the architecture of conidiophores; the presence of denticles; and the size, shape, septation, and ornamentation of conidia (Cooke and Godfrey 1964; Haard 1968) are not sufficient for genus and species delimitation. More recent studies have established a phylogenetic link between the trapping devices used by each species (Rubner 1996; Pfister 1997; Ahrén et al. 1998), and the affiliation of most of these "predaceous" fungi to the Orbiliomycetes (Ascomycota) where they form a monophyletic group (Yang et al. 2007, 2012). Scholler et al. (1999) was the first to draw taxonomic consequences from this by assigning generic rank to groups characterized by different trapping structures, distinguishing four genera and Dactylella for related but non-capturing species. Yu et al. (2014) proposed a reclassification of three genera, namely Arthrobotrys (54 species), Drechslerella (14 species), and Dactylellina (28 species). The fourth genus of Scholler et al. (1999), Gamsylella, was questioned by Li et al. (2005) in their analysis of $28 \mathrm{~S}$ and 5.8S rRNA and $\beta$-tubulin. However, this is still a matter of debate, because the Gamsylella species are moderately distinct also at the molecular level.

Among the predaceous Ascomycota, five types of trapping device can be distinguished, four of which act passively: (i) adhesive three-dimensional networks; (ii) adhesive unicellular knobs either directly attached to the hyphae or on erect stalks; (iii) non-constricting mostly three-celled rings, which often co-occur with adhesive knobs; and (iv) adhesive columns consisting of a few inflated cells on each hypha. The latter type is also found in nematode-trapping genera outside the Ascomycota such as Stylopage spp. and Cystopage spp. (Zoopagales, Zoopagaceae). The fifth and most sophisticated type is the constricting ring trap, which is exclusively found in the genus Drechslerella and captures nematodes actively. When a nematode enters such a trap, the three cells composing the ring swell in a tenth of a second to close the lumen and immobilize the prey. Notably, slowly growing species may form their trapping organs without stimulation, whereas those showing faster saprotrophic growth, mainly Arthrobotrys spp. (Cooke 1968), require external stimuli to induce trap formation. Under natural conditions, the presence of nematodes or nematode secretions (see discussion of paganins A and B below) triggers the formation of these traps (Nordbring-Hertz et al. 2011).

Endoparasitic fungi infect their nematode hosts either via oral uptake or the adhesion of spores or zoospores to the host cuticle. Most of the approximately 50 species of endoparasites are obligate parasites with a broad host range. Once a host has been infected by an endoparasite, the fungus completes its vegetative development within an individual nematode. Endoparasites among the Ophiocordycipitaceae attack nematodes either by oral uptake of non-adhesive spores, which germinate in the alimentary tract (Harposporium spp.), or adhesion of large numbers of conidia to the surface of the hosts (Ophiocordyceps spp., now including Hirsutella spp. and Drechmeria spp., now including Haptocillium spp. ${ }^{1}$ ). Infective zoospores of Catenaria anguillulae (Blastocladiales, Catenariaceae) encyst after physical contact with the nematode is made and adhere to its cuticle. Upon physical contact, the genus Haptoglossa (Haptoglossales, Haptoglossaceae) violently injects immotile tertiary spores into the body of as nematode (Dowe 1987; Nordbring-Hertz et al. 2011). Still far, too little is known about the biocontrol potential of this group; however, it also appears that the host spectrum of some endoparasites is rather limited. The conidia of Drechmeria coniospora, for instance, have been shown to adhere to bacteriovorous, phyto-, and animal-parasitc nematodes. However, this adhesion did not necessarily led to penetration and subsequent infection of the nematodes tested (Jansson 1993).

Nematode egg and female parasites target the immobile stages of economically important genera of cyst and root-knot nematodes such as Globodera, Heterodera, Rotylenchulus, Tylenchulus, and Meloidogyne. Cysts can persist in the soil for several years, so older ones may be colonized by multiple nematophagous and non-nematophagous fungal species.

The three-layer shell of nematode eggs is another target attacked by opportunistically parasitic nematophagous fungi. Most of them use appressoria to mechanically penetrate host eggs (López-Llorca et al. 2008). In some cases, penetration is facilitated by extracellular enzymes such as chitinases and proteases; thus, parasitism by efficient enzyme producers is more prominent (Yang et al. 2007).

Toxin-producing fungi attack their prey by secreting diffusible toxins, and this takes place before any physical contact between the fungus and nematode (López-Llorca et al. 2008). This artificial group comprises basidiomycete genera such as Pleurotus and Coprinus, but also ascomycetes that clearly belong to one of the three aforementioned groups.

\section{Metabolites produced by nematophagous fungi}

\section{Overview}

The chemical ecology of nematophagous fungi is still far from understood. Little has been done to screen for metabolites in nematophagous fungi, or nematicidal metabolites in other fungi, since the pioneering studies by Stadler and colleagues published in the 1990s (Stadler et al. 1993a, b, 1994). The first part of this review article discusses the known metabolites

\footnotetext{
${ }^{1}$ Phylogenetic-based nomenclatural proposals of nematophagous Ophiocordycipitaceae (Hypocreales) were recently published by Quandt et al. (2014).
} 
from nematophagous ascomycetes, whereas the second part will focus on nematicidal metabolites from nematophagous basidiomycetes and non-nematophagous fungi.

\section{Metabolites from nematode-trapping ascomycetes}

Secondary metabolites from nematode-trapping ascomycetes, which either display nematicidal and nematode-attracting activities or regulate the formation of reproductive or trapping organs, are summarized in Fig. 1. Other secondary metabolites from nematode-trapping fungi are depicted in Fig. 2.

Linoleic acid [(9Z,12Z)-octadeca-9,12-dienoic acid] (compound $\mathbf{1}$ ) is regarded as the only bioactive principle in many nematode-trapping fungi. It was originally obtained from submerged cultures of Arthrobotrys conoides Bit 1. The lethal dose (LD) $)_{50}$ against the model nematode Caenorhabditis elegans was determined to be $5-10 \mu \mathrm{g} / \mathrm{ml}$, compared to $0.1 \mu \mathrm{g} / \mathrm{ml}$ for the antihelminthic standard ivermectin. Notably, the number of three-dimensional traps formed by the fungus was positively correlated with the amount of linoleic acid produced (Stadler et al. 1993a). Nematicidal amounts of linoleic acid have also been reported in Arthrobotrys oligospora, Drechslerella brochopaga, and Drechslerella dactyloides (Stadler et al. 1993b).

Metabolites from A. oligospora CBS 115.81 include the three colorless oils: oligosporon, oligosporol $\mathrm{A}$, and oligosporol B (compounds 2-4). The antimicrobial activity of the culture filtrate was detected after $55 \mathrm{~h}$, but the fermentation was continued until the glucose in the medium was used up after $144 \mathrm{~h}$. The formation of compounds 2-4 was also observed on other media and under different fermentation conditions. A. conoides, D. (syn. Dactylella) brochopaga, and D. (syns. Arthrobotrys/Dactylaria) dactyloides were also assigned as producers of these compounds. Among a number of bacteria and yeasts used as test organisms, only Bacillus brevis and Bacillus subtilis displayed moderate susceptibility. All three compounds also exhibited moderately cytotoxic and hemolytic effects, but no phytotoxic or mutagenic activity. The compounds are not nematicidal against $C$. elegans (Stadler et al. 1993b), but the $\mathrm{LD}_{50}$ of oligosporon against larvae of the nematode Haemonchus contortus, which infects ruminants, was subsequently found to be $25 \mu \mathrm{g} / \mathrm{ml}$ (Anderson et al. 1995).

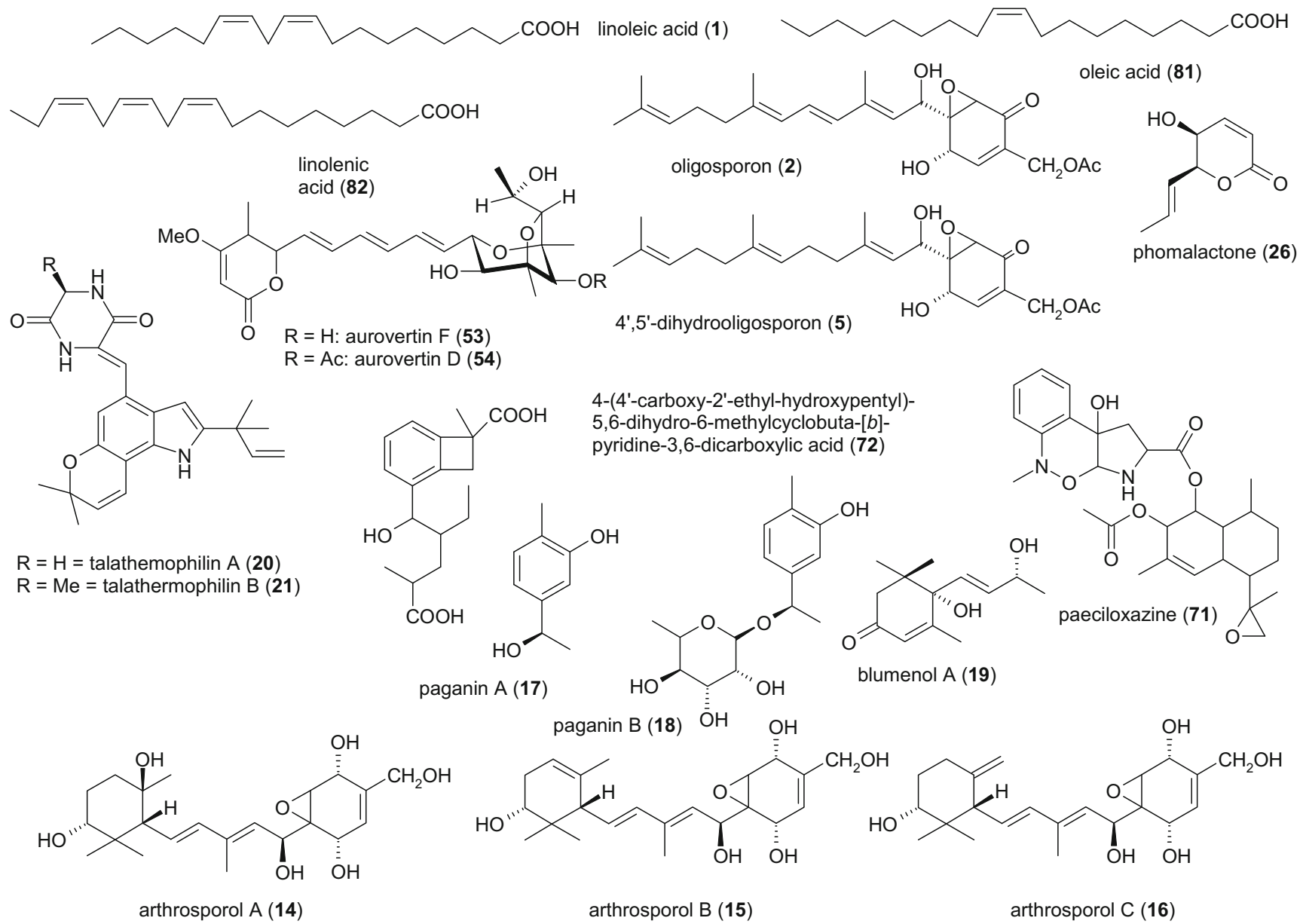

Fig. 1 Secondary metabolites of nematode-trapping, female-, and egg-parasitic fungi, which either display nematicidal (1, 2, 5, 20, 21, 23, 53, 54, 71, $\mathbf{7 2}, \mathbf{8 1}, \mathbf{8 2})$ or nematode-attracting activities (19). Compounds (14-18) auto-regulate the morphology of the producing fungus 

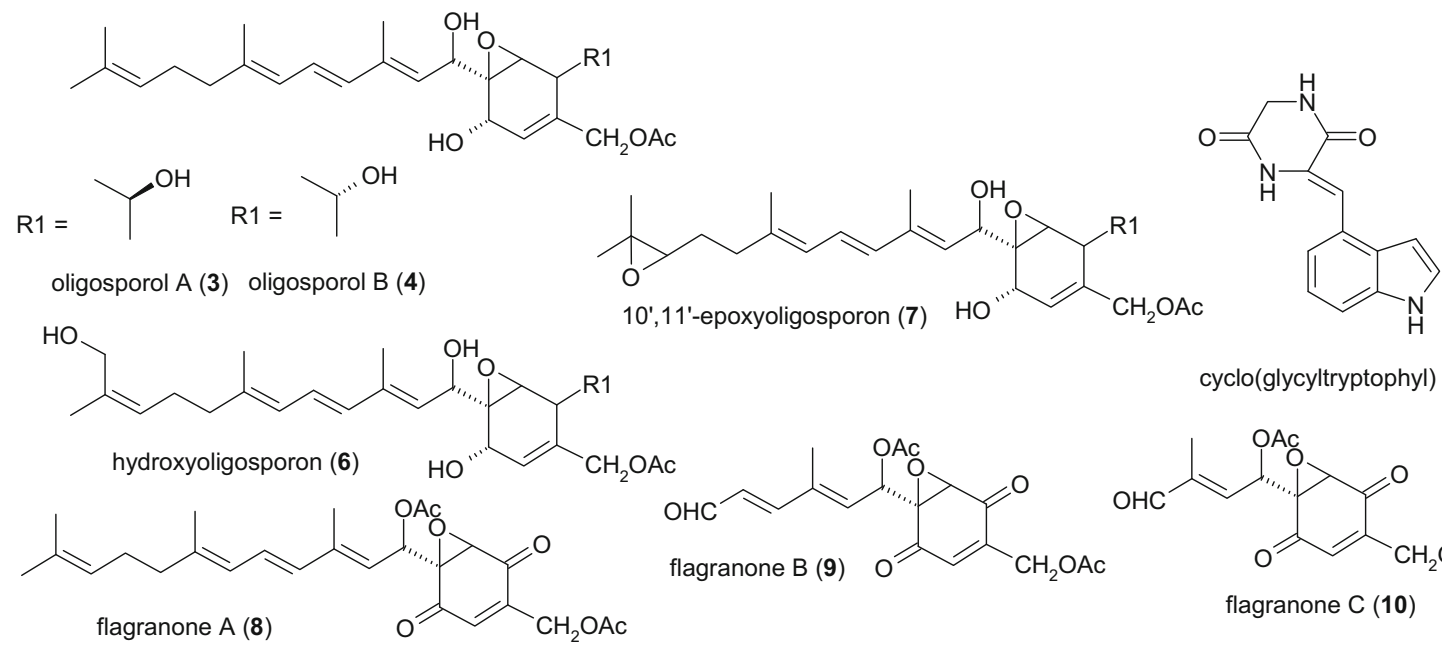

cyclo(glycyltryptophyl) (22)
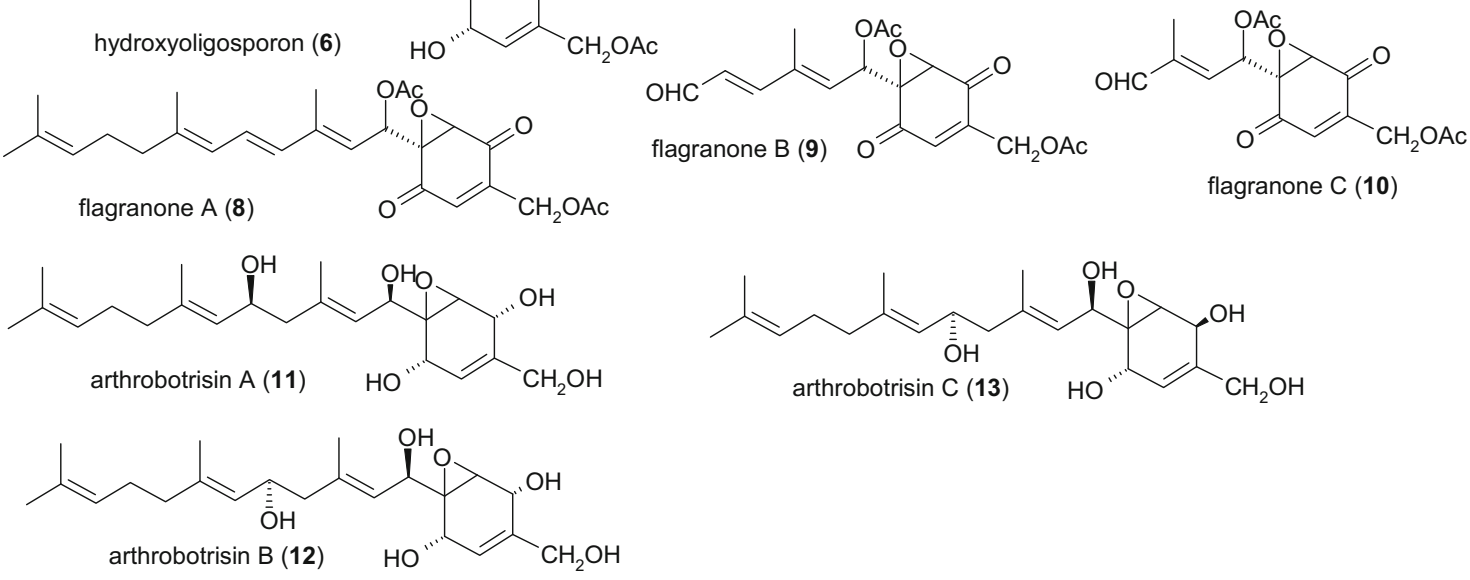

Fig. 2 Other secondary metabolites from nematode-trapping fungi

Three further oligosporon-type metabolites from A. oligospora M2 were identified as $(4 S, 5 R, 6 R)-4^{\prime}, 5^{\prime}-$ dihydrooligosporon, $(4 S, 5 R, 6 R)$-hydroxyoligosporon, and $(4 S, 5 R, 6 R)-10^{\prime} 11^{\prime}$-epoxyoligosporon (compounds 5-7). These were obtained from 7-day-old shaken cultures as three colorless oils. The same strain also produced compounds $\mathbf{2}$, $(4 S, 5 R, 6 R)$-oligosporon, and $\mathbf{4}$, both of which displayed weak antibiotic activity against $B$. subtilis. Compound $\mathbf{4}$ weakly inhibited Streptomyces aureofaciens whereas compound $\mathbf{2}$ weakly inhibited the root rot pathogen Phytophthora cinnamomi. No other activities against Gram-negative bacteria or fungi were observed. Compound $\mathbf{5}$ was the only new compound to display a weak nematicidal activity $\left(\mathrm{LD}_{50}=50\right.$ $100 \mu \mathrm{g} / \mathrm{ml}$ ) against $H$. contortus (Anderson et al. 1995).

Flagranones A, B, and C (compounds 8-10) were produced by a strain of Arthrobotrys flagrans (syn. Duddingtonia flagrans) isolated from cattle feces and cultivated by solidstate fermentation on wheat, oats, and barley grains. After 4 weeks, the grains were combined and extracted, and three yellow oils were obtained that are structurally related to oligosporon (2), suggesting a common biosynthetic metabolic origin. Flagranones A and B were active against $B$. subtilis and $S$. aureofaciens with a minimal inhibitory concentration (MIC) of $25 \mu \mathrm{g} / \mathrm{ml}$. Gram-negative bacteria such as Escherichia coli and Erwinia carotovora were weakly inhibited, and the phytopathogenic fungi P. cinnamomi, Pythium ultimum, and Rhizoctonia solani were partially inhibited. Nematicidal activity in the H. contortus larval development assay was classified as insignificant (Anderson et al. 1999).

Arthrobotrisins A, B, and C (compounds 11-13) are oligosporon-type antibiotics obtained as colorless oils from submerged cultures of A. oligospora YMF 1.3170 after cultivation for 10 days. Strong activity was observed against B. subtilis, but the activity against two other Bacillus species and Staphylococcus aureus were moderate in comparison to the bacteriostatic standard chloramphenicol. None of the arthrobotrisins displayed nematicidal activity against the free-living nematode Panagrellus redivivus (Wei et al. 2011).

Arthrosporols A, B, and C (compounds 14-16) are additional oligosporon-type metabolites carrying a 1,3,3trimethylcyclohexyl ring instead of a farnesyl side chain. They were obtained as amorphous solids from A. oligospora $\mathrm{YMF}$ 1.3170 after 4 days of submerged cultivation at $28{ }^{\circ} \mathrm{C}$. All three substances play an important role in the regulation of fungal morphology. Concentrations of $0.5-5 \mu \mathrm{g} / \mathrm{ml}$ inhibit the formation of conidiophores, with compound $\mathbf{1 6}$ exhibiting the strongest effect (50-90\% inhibition). Compound 16 (at $5 \mu \mathrm{g} / \mathrm{ml}$ ) also inhibited conidial germination within $4 \mathrm{~h}$ by $43 \%$. Notably, compounds $\mathbf{1 4}$ and $\mathbf{1 6}$ triggered the formation of trapping organs, i.e., a three-dimensional network (Zhang et al. 2012). A recent HPLC analysis revealed that arthrosporol A could not be detected anymore after disruption of the polyketide synthase (PKS) gene $A O L \_s 00215 g 283$, which encodes for the biosynthesis of 6-methylsalicylic acid in A. oligospora YMF 1.3170. In comparison to the wild-type strain, the mutant 
$\triangle A O L \_$s $00215 g 283$ showed a tenfold increase in the number of traps formed. The number of nematodes captured by the mutant strain was more than twice as high as in the wild type (Xu et al. 2015). However, a detailed LC-MS/ MS-based study is urgently required to unequivocally characterize the metabolic changes observed. All oligosporon-type antibiotics known to date (compounds 2-16) seem to be of mixed biosynthetic origin; however, no studies addressing this question have been published yet. Obviously, the carbon skeleton is formed by alkylation of a polyketide-derived 7-oxabicyclo[4.1.0]hept-3ene nucleus, whereas the farnesyl side chain originates from isoprenoid precursors (Anderson et al. 1995).

Paganins and other metabolites have also been isolated from Dactylellina entomopaga CBS $642.80 .^{2}$ Paganins A and $\mathrm{B}$ (compounds 17 and 18), 1,2,4-trisubstituted simple phenols, were isolated as two colorless oils from 14-day-old shaken cultures of D. entomopaga (syn. Arthrobotrys entomopaga). As previously observed for compounds $\mathbf{1 4}$ and 16, both paganins inhibited the formation of conidiophores $(25 \mu \mathrm{M}$ of each compound resulted in a $65-75 \%$ reduction). Both compounds slightly inhibited the formation of adhesive knobs (trapping organs) at a concentration of $5 \mu \mathrm{m}$, but $50 \mu \mathrm{M}$ of compound $\mathbf{1 7}$ increased the formation of adhesive knobs by $118 \%$. Spore germination was also inhibited by compounds 17 and 18 (55-75\% inhibition within $12 \mathrm{~h}$ in the presence of $50 \mu \mathrm{m}$ compound $\mathbf{1 7}$, and $40-45 \%$ inhibition within $8 \mathrm{~h}$ in the presence of $50 \mu \mathrm{m}$ compound $\mathbf{1 8}$ ). Compound $\mathbf{1 7}$ and the simultaneously isolated compound $\mathbf{1 9}$ (blumenol A, a so-called bis-nor-isoprenoid of uncertain biosynthetic origin ${ }^{3}$ ) were strong attractants for C. elegans, whereas compound $\mathbf{1 8}$, in which the side chain is substituted with an $\alpha$-6-deoxy-L-mannopyranosyl residue, showed no such effect. Neither of the compounds inhibited B. subtilis or showed nematicidal activity against $P$. redivivus (Wu et al. 2013). D. entomopaga also produces talathermophilins A and B (compounds 20 and 21), two yellow pyranoindole alkaloids with prenylated side chains. ${ }^{4}$ Although these compounds initially appeared to show no nematicidal activity, $400 \mu \mathrm{g} / \mathrm{ml}$ was subsequently shown to inhibit the free-living nematode $P$. redivivus by $38 \%$ (compound 20 ) and $44 \%$ (compound 21), respectively (Chu et al. 2010). Finally, no bioactive properties of the diketopiperazine cyclo(glycyltryptophyl) (compound 22) have been reported thus far (Guo et al. 2011; Wu et al. 2013).

\footnotetext{
${ }^{2}$ Erroneously reported as CBS 642.8 by Wu et al. (2013).

${ }^{3}$ Liu et al. (1999) hypothesized a biosynthetic origin from $(S)-(+)-$ abscisic acid (ABA) by oxidative removal of the two terminal carbon atoms, as the conversion of blumenol A into $(S)-(+)$-ABA has previously been reported by Galbraith and Horn (1973).

${ }^{4}$ A biosynthetic pathway starting from tryptophane, glycine, and alanine was proposed (Guo et al. 2011).
}

\section{Metabolites from fungi that infect eggs and cysts}

Secondary metabolites from fugal pathogens of female nematodes and nematode eggs, which display nematicidal activities, are summarized in Fig. 1. Other secondary metabolites from this group are shown in Fig. 3. Peptaibiotics, including the nematicidal leucinostatins produced by members of this group, are listed in Table 1.

Phomalactone (compound 23) from Pochonia chlamydosporia was previously isolated from Phoma sp., Drechslera sp., Curvularia inaequalis (Pleosporales) and Nigrospora sp. (Trichosphaeriales). It was obtained as a colorless liquid from 14-day-old submerged cultures of strain VC10 (syns. Diheterospora chlamydosporia and Verticillium chlamydosporium). Phomalactone at a concentration of $500 \mathrm{mg} / \mathrm{l}$ exhibited promising inhibitory activity against the second-stage larvae of $M$. incognita in a tomato root invasion assay, comparable to $100 \mathrm{mg} / \mathrm{l}$ of aldicarb standard. However, phomalactone was less toxic than commercial aldicarb and oxamyl standards, and its lethal effect was delayed in the M. incognita mortality assay. The co-isolated major compound monorden (compound 24) showed no activity in either assay (Khambay et al. 2000).

Macrocyclic polyketides containing a 2,4dihydroxybenzoate (resorcylate) residue attached to a 14membered lactone ring system are usually referred to as resorcylic acid lactones (RALs). Biosynthesis of radicicol (displaying D-configuration at $\left.\mathrm{C}^{1} 0^{\prime}\right)^{5}$ has recently been shown to be catalyzed by two iterative polyketide synthases (PKS), one of which is a highly reducing (hrPKS) and the other a nonreducing PKS (nrPKS). Subsequent macrocyclization is mediated by an stereotolerant thioesterase, which is capable of generating the native D- and the enantiomeric L-macrocycle (Heberlig et al. 2014). A number of RALs and an alkaloid were isolated from $P$. chlamydosporia var. catenulata P 0297 (syn. V. chlamydosporium var. catenulatum). Fermentation for $168 \mathrm{~h}$ at $23^{\circ} \mathrm{C}$ in chloride-containing MGP medium led to the isolation of monorden ${ }^{6}$ (compound 24) and its derivative tetrahydromonorden (compound $\mathbf{2 5}$ ) as well as five structurally related compounds named pochonins A-E (compounds 26-30) and the spirocyclic alkaloid pseurotin ${ }^{7}$ (compound 31). The replacement of chloride in the medium with bromide resulted in the isolation of monorden (compound 24); the two major metabolites, monocillins II and III (compounds 32 and 33); and two minor compounds, monocillin II

\footnotetext{
${ }^{5}$ Compared to the radicicol family, the important mycotoxin zearalenone and its derivatives display the opposite $(=\mathrm{L})$ configuration at $\mathrm{C} 10^{\prime}$. Biosynthetic enzymes are only distantly related, so they may have evolved independently from a common ancestor (Heberling et al. 2014).

${ }^{6}$ Originally isolated from Cylindrocarpon destructans var. destructans (syn. Cylindrocarpon radicicola) and thus also widely known as radicicol (Evans and White 1966).

${ }^{7}$ Originally isolated from Pseudeurotium ovalis (Bloch et al. 1976).
} 
<smiles></smiles>

$\mathrm{R}=\mathrm{H}$ : monorden (= radicicol, 24) $\mathrm{R}=$<smiles>CC1OC(CO)C(O)C1O</smiles>

pochonin $\mathrm{K}(\mathbf{4 0})$

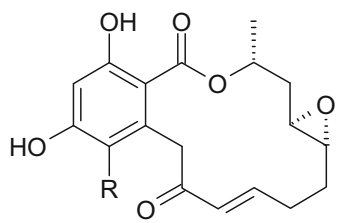

monocillin III (33)<smiles>C[C@@H]1CC[C@H]2CCCCC(=O)Cc3c(Cl)c(O)cc(O)c3C(=O)O[C@@H]1C2</smiles>

tetrahydromonorden (25)<smiles>CC(O)C(O)CC(Cl)/C=C\C=C/C(=O)Cc1c(Cl)c(O)cc(O)c1C(=O)OC(C)C(C)O</smiles>

pochonin C (28)<smiles>[R]c1cc(C(=O)OCC/C=C\CCCC(=O)Cc2c([R])cc(O)cc2[R])c(O)cc1O</smiles>

$\mathrm{R}=\mathrm{H}$ : monocillin IV (48) $\mathrm{R}=\mathrm{Cl}$ : monorden $\mathrm{E}(\mathbf{4 9 )}$<smiles>C[C@H]1CC2OC2C/C=C/C(=O)Cc2c(Cl)c(O)cc(O)c2C(=O)O1</smiles>

pochonin A (26)<smiles>C[C@@H]1CC2OC2CCCCC(=O)Cc2c(Cl)c(O)cc(O)c2C(=O)O1</smiles>

pochonin B (27)<smiles>[R]c1cc(C(=O)OC(C)C(O)/C=C\CC/C=C/C(=O)Cc2c([R])c(O)cc(O)c2C)c(O)cc1O</smiles>

$\mathrm{R}=\mathrm{H}$ : monocillin II (32) $\mathrm{R}=\mathrm{Cl}$ : pochonin D (29)<smiles>[R]c1cc(C(=O)OC(C)C/C=C\C(O)C/C=C/C(=O)Cc2c([R])cc(O)cc2[R])c(O)cc1O</smiles>

$\mathrm{R}=\mathrm{Cl}$ : pochonin $\mathrm{E}(\mathbf{3 0})$

$\mathrm{R}=\mathrm{H}$ : pochonin $\mathrm{F}(\mathbf{3 5})$<smiles>[R]=C=C1OC(C)C(O)C1O</smiles>

monocillin II glucoside (34)

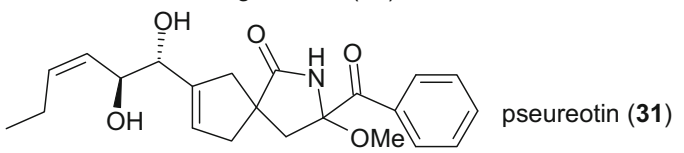<smiles>C[C@H]1CC[C@H](O)Cc2ccc(o2)Cc2c(Cl)c(O)cc(O)c2C1=O</smiles>

pochonin G (36)<smiles>C[C@H]1C/C=C\Cc2ccc(o2)Cc2c(Cl)c(O)cc(O)c2C(=O)O1</smiles>

pochonin $\mathrm{H}$ (37)<smiles>O=C1CC2C(=O)c3ccccc3CC2O1</smiles><smiles>C[C@H]1C[C@H](O)[C@H](O)CCC1CC(=O)Cc1cc(O)cc(O)c1C(=O)O</smiles>

pochonin J (39)<smiles>CO[C@H](C)C[C@H](O)/C=C\C=C/CC(=O)Cc1c(Cl)c(O)cc(O)c1C(=O)O</smiles>

pochonin $L$ (41)<smiles>CO[C@H](C)C[C@@H](O)/C=C\C=C/CC(=O)Cc1c(Cl)c(O)cc(O)c1C(=O)O</smiles>

monorden-analog-1 (46)<smiles>[R]CC([R])/C=C\[C@H](O)C[C@H](C)OC(=O)c1c(O)cc(O)c(Cl)c1CC(=O)CCC</smiles>

$\mathrm{R}=\mathrm{H}$ : pochonin $\mathrm{M}(\mathbf{4 2})$ $\mathrm{R}=\mathrm{OH}$ : pochonin $\mathrm{N}(\mathbf{4 3})$<smiles>C[C@@H]1CCCCC(O)CCC(=O)Cc2c(Cl)c(O)cc(O)c2C(=O)O1</smiles>

pochonin $\mathrm{O}(\mathbf{4 4})$

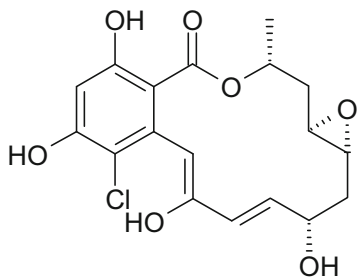

pochonin P (45)<smiles>C[C@@H]1C[C@H](O)/C=C\C=C/C(=O)Cc2c(Cl)c(O)cc(O)c2C(=O)O1</smiles>

monocillin I (47)<smiles></smiles>

13-bromomonocillin I (50)

Fig. 3 Other secondary metabolites from female- and egg-parasitic fungi 


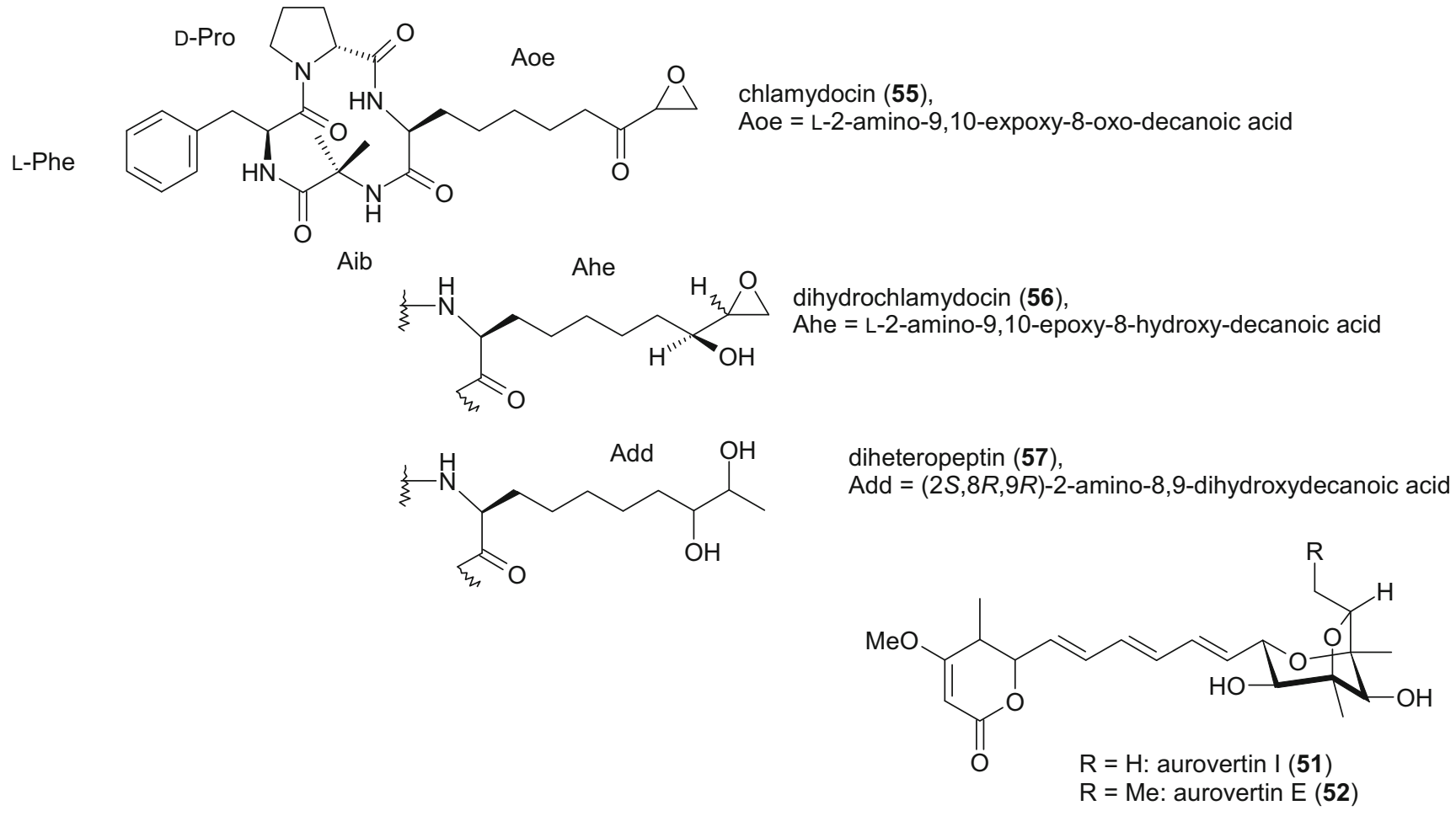<smiles>CC(C)NC[C@@H]1[C@H](O)[C@H](O)[C@@H]2[C@H](O)C[C@@H](CO)N21</smiles>

(+)-pochonicine (58)

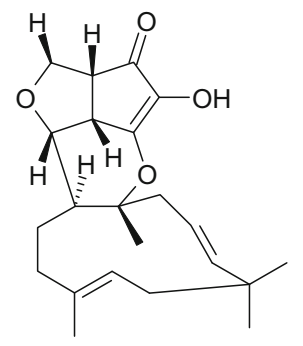

xenovulene A (60)<smiles>CCCCCCC(=O)CCCCCC/C=C/[C@@H](O)[C@H](O)[C@H](O)[C@](N)(CO)C(=O)O</smiles>

sphingofungin $E$ (61)<smiles>CCCCCCC(=O)CCCCCC/C=C/[C@@H](O)[C@H](O)[C@H](O)[C@](C)(N)C(=O)O</smiles>

sphingofungin $F(62)$<smiles>CCC=CC1=C(CCCC(=O)O)C(=O)OC1=O</smiles>

(3Z,5E)-octa-3,5-diene-1,3,4-tricarboxylic acid 3,4-anhydride (65)

Fig. 3 (continued)<smiles>[R]OC(=O)C[C@H]1Cc2cc3cc(OC)cc(O)c3c(O)c2C(=O)O1</smiles>

$\mathrm{R}=$ Me: semiviriditoxin (63)

$\mathrm{R}=\mathrm{H}$ : semiviriditoxic acid $(64)$<smiles>COC(=O)CC1Cc2cc3c(C4CCCC4)c(O)cc(O)c3c(O)c2C(=O)O1</smiles><smiles>CCCCCCCC[C@H]1O[C@@H](OC)c2ccccc21</smiles><smiles>C/C=C1\CC2=C(C(=O)OC2=O)[C@@H](CCC)[C@@H](O)C(=O)C[C@@H]1O</smiles>
cornexistin (70)

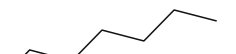

paecilocin $A(66)$

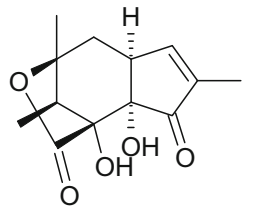

acremostrictin (59)<smiles>CCCCCCC[C@H]1C(=O)C2=CCCC=C2[C@@H]1O</smiles> 
Table 1 Sequences of nematicidal, non-ribosomally biosynthesized peptide antibiotics (peptaibiotics) from Paecilomyces variotii (73) and Purpureocillium lilacinum (75-80)

\begin{tabular}{|c|c|c|c|c|c|c|c|c|c|c|c|c|c|c|c|c|c|c|c|c|c|c|}
\hline \multirow[t]{2}{*}{ No. } & \multicolumn{22}{|l|}{ Residue } \\
\hline & & 1 & 2 & 3 & 4 & 5 & 6 & 7 & 8 & 9 & 10 & 11 & 12 & 13 & 14 & 15 & 16 & 17 & 18 & 19 & 20 & 21 \\
\hline 73 & MOTDA & Pro & Aib & Aib & Aib & Aib & Ala & Ala & Aib & Leu & Ala & Aib & Ala & Ala & Aib & Arg & Ala & Aib & Gly & Aib & Aib & Ala \\
\hline 75 & MeHA & MePro & AHMOD & Hyleu & Aib & Leu & Leu & Aib & Aib & $\beta$-Ala & DPD & & & & & & & & & & & \\
\hline 76 & MeHA & MePro & Leu & Hyleu & Aib & Leu & Leu & Aib & Aib & $\beta$-Ala & DPD & & & & & & & & & & & \\
\hline 77 & MeHA & MePro & Leu & Hyleu & Aib & Leu & Leu & Aib & Aib & $\beta$-Ala & MPD & & & & & & & & & & & \\
\hline 78 & MeHA & MePro & Leu & Hyleu & Aib & Leu & Leu & Aib & Aib & $\beta$-Ala & DPD-NO & & & & & & & & & & & \\
\hline 79 & MeHA & Pro & AHMOD & Hyleu & Aib & Leu & Leu & Aib & Aib & $\beta$-Ala & MPD & & & & & & & & & & & \\
\hline 80 & MeHA & Pro & Leu & Hyleu & Aib & Leu & Leu & Aib & Aib & $\beta$-Ala & MPD & & & & & & & & & & & \\
\hline
\end{tabular}

MOTDA $\beta$-keto-2-methyltetradecanoic acid, MeHA (4S,2E)-4-methylhex-2-enoic acid, MePro cis-4-L-methylproline, $A H M O D$ (2S,4S)-2-amino-6hydroxy-4-methyl-8-oxodecanoic acid, Aib $\alpha$-aminoisobutyric acid, Hyleu threo- $\beta$-L-hydroxyleucine, $\beta$-Ala $\beta$-alanine, $M P D N^{1}$-methyl-propane-1,2diamine, $D P D N^{1} N^{1}$-dimethyl-propane-1,2-diamine, $D P D$ - $N O(2 S)-N^{1}, N^{1}$-dimethyl-propane-1,2-diamine- $N$-oxide

glucoside (compound 34) and pochonin F (compound 35). Whereas monocillins I-III were isolated as colorless solids, monocillin IV and the pochonins were isolated as brownish or colorless oils. Most of these compounds were moderately active against Herpes simplex virus type I (HSV-1) and Eimeria tenella, the agent responsible for hemorrhagic cecal coccidiosis in poultry. They were also cytotoxic. The remarkably broad spectrum of biological activities previously reported for monorden (compound 24), which has previously been isolated from Monocillium nordinii (Niessliaceae, Hypocreales) ${ }^{8}$ and other fungi, was also demonstrated. The native role of compounds 24-35 is unclear because they did not modulate the activity of the human estrogenic receptor $\operatorname{ER} \beta$ (Hellwig et al. 2003) unlike zearalenone and its derivatives (Frisvad et al. 2006).

Additional RALs were isolated from P. chlamydosporia var. chlamydosporia FERM BP-8332 (strain TF-0480) during a screen for WNT-5a inhibitors (Shinonaga et al. 2009a). This strain produced monorden (compound 24) and four novel RALs named pochonins G-J (compounds 36-39). A more detailed investigation of the same strain yielded four known RALs, i.e., pochonins B, D, E, and F (compounds 27, 29, 30, and 35) as well as the novel pochonins K-P (compounds 4045). Further RALs from the same fermentation comprised monorden analog-1 (compound 46) and monocillins I-IV (compounds 47, 32, 33, and 48) as well as monorden E (compound 49) (Shinonaga et al. 2009b). When the growth medium was supplemented with sodium bromide, the fermentation also yielded 13-bromomonocillin (compound 50) (Shinonaga et al. 2009c).

Four of the 19 aurovertins (A-S) known to date were retrieved from $P$. chlamydosporia YMF 1.00613 by passing infected $M$. incognita juveniles from tobacco root knots through a Baermann funnel and cultivating the fungi in submerged culture for 12 days at $28{ }^{\circ} \mathrm{C}$.

\footnotetext{
${ }^{8}$ For details, see Ayer et al. (1980)
}

This resulted in the recovery of the novel compound aurovertin I (compound 51) as well as three other yellow oils representing the known aurovertins E, F, and D (compounds 52-54). After $48 \mathrm{~h}$, the major aurovertins $\mathrm{D}$ and $\mathrm{F}$ displayed nematicidal activity towards the freeliving species $P$. redivivus with $\mathrm{LC}_{50}$ values of 41.7 and $88.6 \mu \mathrm{g} / \mathrm{ml}$, respectively. However, the four aurovertins were unable to prevent $M$. incognita eggs from hatching at concentrations of $25-400 \mu \mathrm{g} / \mathrm{ml}$, and the inhibitory efficacy was below $5 \%$ (Niu et al. 2010). In a recent study, aurovertin D (compound 54) was strongly toxic towards $M$. incognita and affected $C$. elegans even at sub-inhibitory concentrations. DAF-2, an evolutionary conserved insulin/IGF-1-like receptor, is required for timing of larval development in $C$. elegans, whereas DAF-16 is a $C$. elegans FOXO transcription factor acting as a key mediator for multiple stress responses. Consequently, resistance of C. elegans daf-2 (e1370) and hypersensitivity of $C$. elegans daf-16 (mu86) to aurovertin D indicated that DAF-16/FOXO transcription factor in nematodes was triggered in response to aurovertin (Wang et al. 2015). The 2,6dioxabicyclo[3.2.1]octane (DBO) ring system found throughout the aurovertin family. Briefly, a hexaene pyrone is biosynthesized by highly reducing PKS, AurA. Next, the $\mathrm{OH}$-group of this pyrone is methylated by an $O$-methyltransferase. A flavin-dependent monooxygenase and an epoxide hydrolase convert the triene side chain into the dioxabicyclo[3.2.1] octane scaffold (Mao et al. 2015).

The interconvertible cyclotetrapetaibiotics (Degenkolb et al. 2008) chlamydocin (compound 55) and dihydrochlamydocin (compound 56) were obtained from P. chlamydosporia NRRL 3472 culture filtrates after fermentation for $90 \mathrm{~h}$. Pure chlamydocin appears as white foam, whereas dihydrochlamydocin forms white crystals. Both substances 
showed strong cytostatic activity towards mastocytoma cells (Closse and Huguenin 1974) and inhibited histone deacetylases (Islam et al. 2012). Another cyclotetrapetaibiotic, ${ }^{9}$ diheteropeptin (compound 57), was obtained as a white powder from submerged cultures of $P$. chlamydosporia Q58044 after 5 days. This metabolite mimics the activity of transforming growth factor beta $(\mathrm{TGF} \beta)$ and inhibits histone deacetylase (Masuoka et al. 1997, 2000a, b). These three compounds have yet to be tested for their nematicidal effects.

The polyhydroxylated pyrrolizidine alkaloid pochonicine (compound 58) was isolated from Pochonia suchlasporia var. suchlasporia TAMA 87 as colorless syrup during solidstate fermentation. This compound is a potent inhibitor of $\beta$ $N$-acetylglucosaminidases from diverse sources, including fungi, insects, mammals, and plants (Usuki et al. 2009). The structure of pochonicine was recently revised to be $(+)-(1 R, 3 S$, $5 R, 6 R, 7 S, 7 \mathrm{a} R$ )-pochonicine (Zhu et al. 2013).

The tricyclic lactone acremostrictin (compound 59) was recently isolated from the polyphagous species Acremonium (now Sarocladium) strictum ${ }^{10}$ MB05005, ${ }^{11}$ which originated from an unidentified Choristida sponge. $S$. strictum is known as an aggressive parasite of $H$. schachtii eggs (Nigh et al. 1980). The compound was isolated from the filtrate of a 3-week-old submerged culture of a marine isolate. It shows weak antibacterial and moderate antioxidant activities, but additional effects have not been reported thus far (Julianti et al. 2011).

The oxygenated humulene-derived sesquiterpene xenovulene A (60) carries an 11-membered ring system, which probably originates from polyketide synthesis. It was isolated from the mycelium of a 5-day-old fermentation of A. strictum IMI 354451 . The compound inhibits the binding of flunitrazepam to the benzodiazepine site of the $\gamma$-aminobutyric acid $(\mathrm{GABA})_{\mathrm{A}}$ receptor with an $\mathrm{IC}_{50}$ value of $40 \mathrm{nM}$ (Ainsworth et al. 1995).

Two sphingolipids, sphingofungins $\mathrm{E}$ and $\mathrm{F}$ (compounds 61 and 62), were isolated from a 14-day-old solid-state fermentation of Paecilomyces variotii ATCC $74097,{ }^{12}$ a species that parasitizes the eggs of the soybean cyst nematode Heterodera glycines among others (Dowe 1987). Both compounds are sphingosine-like inhibitors of serinepalmitoyl transferase. Sphingofungin E (compound 61) showed moderate antifungal activity, whereas sphingofungin $\mathrm{F}$ (compound 62) was comparatively weak (Horn et al. 1992).

\footnotetext{
${ }^{9}$ Peptaibiotics have comprehensively been reviewed by Degenkolb and Brückner (2008), including comments on non-ribosomal peptide biosynthesis and modes of action.

${ }^{10}$ For phylogenetic re-evaluation of the genus Acremonium, see Summerbell et al. (2011) and Giraldo et al. (2015).

${ }^{11}$ Nematicidal bioactivities have not been reported for any of the 218 Acremonium-derived metabolites that are currently listed in AntiBase (Laatsch 2014).

${ }^{12}$ With the exception of compounds described in this review, nematicidal bioactivities have not been reported for any of the 181 Paecilomycesderived metabolites that are currently listed in AntiBase (Laatsch 2014).
}

The entomopathogenic fungal strain $P$. variotii UAMH 6353 isolated from larvae of the mountain pine beetle Dendroctonus ponderosae has been shown to produce two polyketide metabolites derived from $1 H$-naphtho[2,3c]pyran1 -one (naphthopyranone). The mycelium of a 3-week-old surface culture produced $(S)$-semi-viriditoxin (compound 63) and $(S)$-semi-viriditoxic acid (64) was present in the mycelium and culture filtrate. Both metabolites exhibited weak antibacterial but no antifungal activity (Ayer et al. 1991).

A tricarboxylic acid anhydride has been isolated from a 5day-old fermentation of $P$. variotii ICI No. 3142. The culture filtrate contained (3Z,5E)-octa-3,5-diene-1,3,4-tricarboxylic acid 3,4-anhydride (compound 65) (Aldridge et al. 1980) .

Four polyketides named paecilocins A-D (compounds 6669) were obtained from $P$. variotii J08NF-1, isolated as a symbiont of the jellyfish Nemopilema nomurai. Paecilocin A, also known as (S)-7-hydroxy-3-octylphthalide or (3S)-7-hydroxy3-octyl-2-benzofuran-1(3H)-one, appears as a white amorphous powder, whereas paecilocins $\mathrm{B}((1 S, 3 S)-1,3$ dimethoxy-1-octyl-1,3-dihydro-2-benzofuran-4-ol), C ((1S, $3 R$ )-1,3-dimethoxy-1-octyl-3H-2-benzofuran-4-ol) and $\mathrm{D}$ $((2 R, 3 R)-2$-heptyl-3,4-dihydroxyindan-1-one) are yellow oils. Compounds 66-68 displayed remarkable antibacterial activity (MICs ranging from 5 to $40 \mu \mathrm{g} / \mathrm{ml}$ ) against S. aureus, including the methicillin-resistant strain 3089 and the multidrugresistant Vibrio parahaemolyticus 7001 (Liu et al. 2011).

Cornexistin $((4 \mathrm{R}, 5 R, 8 R)$-9-ethylidene-4,5,7,8,9,10hexahydro-5,8-dihydroxy-4-propyl-1 $H$-cyclonona[c]furan-1, 3,6-trione; compound 70) was isolated as colorless crystals from P. variotii strain ATCC 74286 (= FERM BP$1351=$ SANK 21086) sourced from deer dung, during a screen for microbial secondary metabolites with herbicidal activity (Nakajima et al. 1991). The maximum concentration of this nonadride ${ }^{13}$ was achieved after $161 \mathrm{~h}$ of fermentation at $26{ }^{\circ} \mathrm{C}$. Although cornexistin lacks antimicrobial activity, it showed strong post-emergence herbicidal activity against young annual and perennial monocotyledonous and dicotyledonous weeds but no activity against maize plants.

The pyrrolobenzoxazine paeciloxazine (compound 71) was isolated from submerged cultures of Paecilomyces sp. BAUA3058 after $120 \mathrm{~h}$ at $25^{\circ} \mathrm{C}$, during a screen for novel nematicidal metabolites. After 4 days of incubation, the MIC against the nematode Rhabditella axei (syn. Rhabditis pseudoelongata) was $50 \mu \mathrm{g} / \mathrm{ml}$, compared to $0.125 \mu \mathrm{g} / \mathrm{ml}$ for the standard ivermectin. Paeciloxazine also showed insecticidal activity towards Culex pipiens pallens $\mathrm{L}_{2}$ larvae, with a MIC of $25 \mu \mathrm{g} / \mathrm{ml}$ after $24 \mathrm{~h}, 40$-fold lower than the standard imidacloprid. The $\mathrm{LD}_{50}$ against Plutella xylostella $\mathrm{L}_{3}$ larvae was $250 \mu \mathrm{g} / \mathrm{ml}$ (Kanai et al. 2004).

\footnotetext{
${ }^{13}$ Fungal metabolites containing a nine-membered ring fused to one or two maleic anhydride. A hypothetic scheme for biosynthesis of these compounds was recently published (Szwalbe et al. 2015).
} 
A nematicidal metabolite has also been isolated from Paecilomyces sp. YMF 1.0716. Extracts from 40 strains of Paecilomyces spp. cultivated for 15 days at $25{ }^{\circ} \mathrm{C}$ were tested for nematicidal activity, and the most active extract yielded the white crystalline compound, 4-(4'-carboxy-2'-ethylhydroxypentyl)-5,6-dihydro-6-methylcyclobuta[b]pyridine-3, 6-dicarboxylic acid (compound 72). $\mathrm{LD}_{50}$ values were determined against three nematodes: $P$. redivivus $(52.4 \mu \mathrm{g} / \mathrm{ml})$, M. incognita $(47.1 \mu \mathrm{g} / \mathrm{ml})$, and Bursaphelenchus xylophilus $(167.7 \mu \mathrm{g} / \mathrm{ml})($ Liu et al. 2009).

Two antifungal peptaibiotics were isolated from the culture filtrate of $P$. variotii SCF 1559 after $24 \mathrm{~h}$, the 21 -residue peptide SCH 643432 (compound 73) and a structurally unresolved positional isomer (compound 74, not shown). Both compounds were active against Candida albicans and other Candida species as well as dermatophytes of the genus Trichophyton (Hegde et al. 2003).

Thus far, 25 leucinostatins have been isolated from various strains of Purpureocillium lilacinum ${ }^{14}$ (Fukushima et al. 1983a, b; Isogai et al. 1992; Martinez and Moraes 2015). Although these lipoaminopeptides, a subclass of membrane-active peptaibiotics, have been known since 1973 (Degenkolb and Brückner 2008), their nematicidal activity against $C$. elegans was not reported until Park et al. (2004) investigated the properties of 20 Australian isolates of $P$. lilacinum. The three most potent isolates were shown to produce a mixture of leucinostatins, among which leucinostatins B, D, F, H, L, and T could be identified (compounds 75-80). When tested against a mixed population of C. elegans juveniles and adults, this leucinostatin mixture achieved $77 \%$ mortality after $2 \mathrm{~h}$ and $100 \%$ mortality after $12 \mathrm{~h}$, at an overall concentration of $100 \mu \mathrm{g} / \mathrm{ml}$, and $74 \%$ mortality after $24 \mathrm{~h}$ at an overall concentration of $10 \mu \mathrm{g} / \mathrm{ml}$. Egg hatching was not influenced by leucinostatins, but the $100 \mu \mathrm{g} / \mathrm{ml}$ solution killed $100 \%$ of C. elegans $\mathrm{L}_{2}$ larvae after $24 \mathrm{~h}$, and the $10 \mu \mathrm{g} / \mathrm{ml}$ solution killed $78 \%$ of the $\mathrm{L}_{2}$ larvae after $24 \mathrm{~h}$. Five other leucinostatin-negative strains were shown to produce oleic acid, also known as (9Z)-octadecenoic acid (compound $\mathbf{8 1}$ ), linoleic acid (compound $\mathbf{1}$ ), and linolenic acid, also known as $(9 Z, 12 Z, 15 Z)$-octadeca-9,12,15-trienoic acid (compound 82) (Park et al. 2004), all of which have nematicidal activity (Stadler et al. 1993a, 1994). The nematicidal activity of these strains is also enhanced by their secretion of chitinases (Park et al. 2004). Sequences of linear peptaibiotics reviewed here are listed in Table 1.

\section{Outlook and perspectives}

Among the approximately 30,000 known natural products from fungi, 15,000-16,000 are considered to be

\footnotetext{
${ }^{14}$ The current name of Paecilomyces lilacinus is Purpureocillium lilacinum (Luangsa-ard et al. 2011). However, it appears that the new name is still rarely used in the biocontrol literature.
}

bioactive and almost 12,000 of them have been isolated from microscopic fungi (Bérdy 2012). For example, the beneficial role of antifungal peptidic and non-peptidic secondary metabolites in commercial biocontrol agents formulated with species of the Trichoderma harzianum complex (Chaverri et al. 2015) has recently been demonstrated (Degenkolb et al. 2015).

Few fungal secondary metabolites have been tested for their potential nematicidal activities, and the systematic screening of fungal natural product libraries could therefore reveal the previously unknown nematicidal or antihelmintic activities of known secondary metabolites (Laatsch 2014). However, there are no standardized protocols for the quantitative determination of nematicidal activity, and compounds that are active against model nematodes used in bioactivity assays may not be active against field pests and vice versa (Anderson et al. 1995).

Several issues remain to be resolved before nematophagous fungi can be used for the biocontrol of nematodes. First, many nematophagous fungi are facultative parasites. This is desirable because artificial mass production of propagules is required to achieve a positive costbenefit ratio, but species and strains that grow well under artificial, saprotrophic conditions may be less inclined to parasitize pest nematodes in the field, and antagonists that capture nematodes efficiently may not establish well in the soil (Cooke 1968). Second, the host range of many nematophagous species is comparatively narrow, as exemplified above for $D$. coniospora. Consequently, parasites of root-knot nematodes may not be able to parasitize eggs (Moosavi and Zare 2012). Third, it is important to note that many nematicidal metabolites produced by fungi are comparatively unstable, including unsaturated fatty acids (compounds 1, 81, 82), oligosporon-type antibiotics (compounds 2-16), and RALs (compounds 24-30, 32-50). It is therefore unlikely that such compounds could be used in their pure forms, although they may play a hitherto unknown role following direct contact between a nematophagous fungus and its nematode hosts (Hellwig et al. 2003, Stadler et al. 2003). Finally, health and safety aspects must be considered before a nematophagous fungus can be registered as an agricultural biocontrol agent, as illustrated by the following two examples.

As stated above, different strains of $P$. variotii (syn. for teleomorph Byssochlamys spectabilis) can produce herbicidal, insecticidal, and nematicidal secondary metabolites (compounds 70-72), but some strains also produce viriditoxin, the C-6/C-6' dehydro dimer of semi-viriditoxin (compound 83), (Houbraken et al. 2006), which is a mycotoxin in a strict sense (Frisvad et al. 2006). Structurally related compounds such as semi-viriditoxin (compound $\mathbf{6 3}$ ) and semi-viriditoxic acid (compound 64) could therefore exhibit similar, undesirable effects towards vertebrates. 
Although P. lilacinum (syn. Paecilomyces lilacinus) is a ubiquitous, saprotrophic soil-borne species, which is regularly found as a pathogen of nematodes and insects, it is also pathogenic to humans and other animals. Some strains of this species cause keratitis, but pathogenic and non-pathogenic strains cannot be distinguished based on their ribosomal RNA internal transcribed spacer or transcriptional enhancer factor $1 \alpha$ sequences (Luangsa-ard et al. 2011). The pronounced heterogeneity of the aggregate species $P$. lilacinum has already led to the description of two additional species, Purpureocillium lavendulum (Perdomo et al. 2013) and Purpureocillium takamizusanense ${ }^{15}$ (Ban et al. 2015). However, Eberhard et al. (2014) emphasized that P. lilacinum (sensu Luangsa-ard) is far more diverse with regard to habitat, geographical distribution, and especially ITS sequence homology. This may ultimately lead to the delimitation of the nematode pathogens from human-pathogenic and other strains. Recently, a fourth official combination, Purpureocillium atypicolum, was published by Spatafora et al. (2015). The genus is currently supposed to encompass all purple- to lilac-spored species previously classified in Nomuraea, although they have not been validly combined yet. However, many more species are expected to belong to Purpureocillium (Gams W, personal communication).

The decline in the availability of chemical measures for efficient nematode control is a challenge that must be met by intensifying the search for environmentally beneficial and cost-efficient alternatives. Nematophagous fungi provide a largely unexploited yet promising reservoir of novel nematicides, which could be used for the biocontrol of phytoparasitic nematodes.

Acknowledgments We acknowledge the financial support provided by the Hessen State Ministry of Higher Education, Research and the Arts (HMWK) including a generous grant for the LOEWE research center "Insect Biotechnology and Bioresources" to A.V. The authors thank Richard M. Twyman for the editing of the manuscript.

\section{Compliance with ethical standards}

Conflict of interest The authors declare that they have no competing interests.

Open Access This article is distributed under the terms of the Creative Commons Attribution 4.0 International License (http:// creativecommons.org/licenses/by/4.0/), which permits unrestricted use, distribution, and reproduction in any medium, provided you give appropriate credit to the original author(s) and the source, provide a link to the Creative Commons license, and indicate if changes were made.

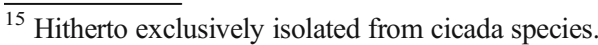

\section{References}

AGES (2015) Austrian Agency for Health and Food Safety and Federal Office for Food Safety. List of authorised/approved plant protection products in Austria. http://pmg.ages.at/pls/psmlfrz/pmgweb4\$. Startup. Accessed 13 July 2015

Ahrén D, Ursing BM, Tunlid A (1998) Phylogeny of nematode-trapping fungi based on 18S rDNA sequences. FEMS Microbiol Lett 158:179-184

Ainsworth AM, Chicarelli-Robinson MI, Copp BR, Fauth U, Hylands PJ, Holloway JA, Latif M, O’Beirne GB, Porter N, Renno DV, Richards M, Robinson N (1995) Xenovulene A, a novel GABAbenzodiazepine receptor binding compound produced by Acremonium strictum. J Antibiot 48:568-573

Aldridge DC, Carman RM, Moore RB (1980) A new tricarboxylic acid anhydride from Paecilomyces variotii. J Chem Soc Perkin Trans I: 2134-2135

Anderson MG, Jarmin TB, Rickards RW (1995) Structures and absolute configurations of antibiotics of the oligosporon group from the nematodetrapping fungus Arthrobotrys oligospora. J Antibiot 48:391-398

Anderson MG, Rickards RW, Lacey E (1999) Structures of flagranones $\mathrm{A}, \mathrm{B}$ and $\mathrm{C}$, cyclohexenoxide antibiotics from the nematodetrapping fungus Duddingtonia flagrans. J Antibiot 52:1023-1028

Ayer WA, Lee SP, Tsuneda A, Hiratsuka Y (1980) The isolation, identification and bioassay of the metabolites produced by Monocillium nordinii. Can J Microbiol 26:766-773

Ayer WA, Craw PA, Nozawa K (1991) Two $1 H$-naphtho[2,3-c]pyran-1one metabolites from the fungus Paecilomyces variotii. Can J Chem 69:189-191

Ban S, Azuma Y, Sato H, Suzuki K-i, Nakagiri A (2015) Isaria takamizusanensis is the anamorph of Cordyceps ryogamimontana, warranting a new combination, Purpureocillium takamizusanense comb. nov. Int J Syst Evol Microbiol 65:2459-2465

Bérdy J (2012) Thoughts and facts about antibiotics: where we are now and where we are heading. J Antibiot 65:385-395, Corrigendum in: J Antibiot 65:441

Bloch P, Tamm C, Bollinger P, Petcher TJ, Weber HP (1976) Pseurotin, a new metabolite of Pseudeurotium ovalis Stolk having an unusual hetero-spirocyclic system. Helv Chim Acta 59:133-137

BLW (2015) Schweizerische Eidgenossenschaft - Bundesamt für Landwirtschaft. Pflanzenschutzmittelverzeichnis (Stand: 16.06.2015) http://www.blw.admin.ch/psm/produkte/index.html? lang=de. Accessed 13 July 2015

Börner H (2009) Pflanzenkrankheiten und Pflanzenschutz. 8., neu bearbeitete und aktualisierte Aufl. Springer Verlag, Berlin

BVL (2015) Federal office of consumer protection and food safety. Register of plant protection products. http://www.bvl.bund.de/DE/ 04_Pflanzenschutzmittel/01_Aufgaben/02_ZulassungPSM/01_ ZugelPSM/05_Verzeichnis/psm_ZugelPSM_Verzeichnis_node. html;jsessionid $=$ EA1675D589C72C38224F5CB582168048.2 cid340. Accessed 13 July 2015

Chaverri P, Branco-Rocha F, Jaklitsch W, Gazis R, Degenkolb T, Samuels GJ (2015) Systematics of the Trichoderma harzianum species complex and the re-identification of commercial biocontrol strains. Mycologia 107:558-590

Chitwood N (2003) Nematicides. In: Plimmer JR, Ragsdale NR, Gammon D (eds) Encyclopedia of agrochemicals, vol 3. John Wiley and Sons, New York, pp 1104-1115

Chu Y-S, Niu X-M, Wang Y-L, Guo J-P, Pan W-Z, Huang X-W, Zhang K$Q$ (2010) Isolation of putative biosynthetic intermediates of prenylated indole alkaloids from a thermophilic fungus Talaromyces thermophilus. Org Lett 12:4356-4359

Closse A, Huguenin R (1974) Isolierung und Strukturaufklärung von Chlamydocin. Helv Chim Acta 57:533-545

Cooke R (1968) Relationship between nematode-destroying fungi and soil-borne phytonematodes. Phytopathology 58:909-913 
Cooke RC, Godfrey BES (1964) A key to the nematode-destroying fungi. Trans Br Mycol Soc 47:61-74

Degenkolb T, Brückner H (2008) Peptaibiomics: towards a myriad of bioactive peptides containing $\mathrm{C}^{\alpha}$-dialkylamino acids? Chem Biodivers 5:1817-1843

Degenkolb T, Gams W, Brückner H (2008) Natural cyclopeptaibiotics and related cyclic tetrapeptides: structural diversity and future prospects. Chem Biodivers 5:693-706

Degenkolb T, Nielsen KF, Dieckmann R, Branco-Rocha F, Chaverri P, Samuels GJ, Thrane U, von Döhren H, Vilcinskas A, Brückner H (2015) Peptaibol, secondary-metabolite, and hydrophobin pattern of commercial biocontrol agents formulated with species of the Trichoderma harzianum complex. Chem Biodivers 12:662-684

Dowe A (1987) Räuberische Pilze und andere pilzliche Nematodenfeinde. 2., neubearbeitete Auflage. Die Neue Brehm-Bücherei 449. A. Ziemsen Verlag, Wittenberg

Eberhard W, Pacheco-Esquivel J, Carrasco-Rueda F, Christopher Y, Gonzalez C, Ramos D, Urbina H, Blackwell M (2014) Zombie bugs? The fungus Purpureocillium cf. lilacinum maymanipulate the behavior of its host bug Edessa rufomarginata. Mycologia 106: $1065-1072$

EFSA (2010) European Food Safety Authority: conclusion on the peer review of the pesticide risk assessment of the active substance dazomet. EFSA J 8:1833-1923

Evans G, White NH (1966) Radicicolin and radicicol, two new antibiotics produced by Cylindrocarpon radicicola. Trans Br Mycol Soc 49: 563-576

Frisvad JC, Thrane U, Samson RA, Pitt J (2006) Important mycotoxins and the fungi which produce them. Adv Exp Med Biol 571:3-31

Fukushima K, Arai T, Mori Y, Tsuboi M, Suzuki M (1983a) Studies on peptide antibiotics, leucinostatins. I. Separation, physico-chemical properties and biological activities of leucinostatins A and B. J Antibiot 36:1606-1612

Fukushima K, Arai T, Mori Y, Tsuboi M, Suzuki M (1983b) Studies on peptide antibiotics, leucinostatins. II. The structures of leucinostatins A and B. J Antibiot 365:1613-1630

Galbraith, MN, Horn DHS (1973) Stereochemistry of the blumenols: conversion of blurnenol A into $(S)-(+)$-abscisic acid. J Chem Soc Chem Commun: 566-567

Giraldo A, Gené J, Sutton DA, Madrid H, de Hoog GS, Cano J, Decock C, Crous PW, Guarro J (2015) Phylogeny of Sarocladium (Hypocreales). Persoonia 34:10-24

Guo J-P, Tan J-L, Wang Y-L, Wu H-Y, Zhang C-P, Niu X-M, Pan W-Z, Huang X-W, Zhang K-Q (2011) Isolation of talathermophilins from the thermophilic fungus Talaromyces thermophilus YM3-4. J Nat Prod 74:2278-2281

Haard K (1968) Taxonomic studies on the genus Arthrobotrys Corda. Mycologia 60:1140-1159

Heberlig GW, Wirz M, Wang M, Boddy CN (2014) Resorcylic acid lactone biosynthesis relies on a stereotolerant macrocyclizing thioesterase. Org Lett 16:5858-5861

Hegde VR, Silver J, Patel M, Gullo VP, Puar MS, Das PR, Loebenberg D (2003) Novel fungal metabolites as cell wall active antifungals: fermentation, isolation, physico-chemical properties, structure and biological activity. J Antibiot 56:437-447

Hellwig V, Mayer-Bartschmid A, Müller H, Greif G, Kleymann G, Zitzmann W, Tichy HV, Stadler M (2003) Pochonins A-F, new antiviral and antiparasitic resorcylic acid lactones from Pochonia chlamydosporia var. catenulata. J Nat Prod 66:829-837

Horn WS, Smith JL, Bills GF, Raghoobar SL, Helms GL, Kurtz MB, Marrinan JA, Frommer BR, Thornton RA, Mandala SM (1992) Sphingofungins $\mathrm{E}$ and $\mathrm{F}$, novel serinepalmitoyl transferase inhibitors from Paecilomyces variotii. J Antibiot 45:1692-1696

Houbraken J, Samson RA, Frisvad JC (2006) Byssochlamys: significance of heat resistance and mycotoxin production. Adv Exp Med Biol 571:211-224
Hugot JP, Baujard P, Morand S (2001) Biodiversity in helminths and nematodes as a field of study: an overview. Nematology 3:199-208

Hunt DJ, Handoo ZA (2009) Taxonomy, identification and principal species. In: Perry RN, Moens M, Starr JL (eds) Root-knot nematodes. CABI, Walliongford, pp 55-97

Islam MS, Bhuiyan MPI, Islam MN, Nsiama TK, Oishi N, Kato T, Nishino N, Ito A, Yoshida M (2012) Evaluation of functional groups on amino acids in cyclic tetrapeptides in histone deacetylase inhibition. Amino Acids 42:2103-2110

Isogai A, Nakayama J, Takayama S, Kusai A, Suzuki A (1992) Structural elucidation of minor components of peptidyl antibiotic P168s (leucinostatins) by tandem mass spectrometry. Biosci Biotechnol Biochem 56:1079-1085

Jansson H-B (1993) Adhesion to nematodes of conidia from the nematophagous fungus Drechmeria coniospora. J Gen Microbiol 139:1899-1906

Jansson H-B, López-Llorca LV (2004) Control of nematodes by fungi. In: Arora DK (ed) Fungal biotechnology in agriculture, food, and environmental applications. Marcel Dekker, New York, pp 205-215

Julianti E, Oh H, Jang KH, Lee JK, Lee SK, Oh D-C, Oh K-B, Shin J (2011) Acremostrictin, a highly oxygenated metabolite from the marine fungus Acremonium strictum. J Nat Prod 74:2592-2594

Kanai Y, Fujimaki T, Kochi S-I, Konno H, Kanazawa S, Tokumasu S (2004) Paeciloxazine, a novel antibiotic from Paecilomyces sp. J Antibiot 57:24-28

Khambay BPS, Bourne JM, Cameron S, Kerry BR, Zaki MJ (2000) A nematicidal metabolite from Verticillium chlamydosporium. Pest Manag Sci 56:1098-1099

KWS Saat AG (2012) Nematoden: Erkennen - Handeln - Erträge sichern. Eigenverlag, Einbeck

Laatsch H (2014) Antibase 2014 SciDex v. 1.2.495 - The natural compounds identifier. Wiley-VCH, Weinheim

Li Y, Hyde KD, Jeewon R, Cai L, Vijaykrishna D, Zhang K-Q (2005) Phylogenetics and evolution of nematode-trapping fungi (Orbiliales) estimated from nuclear and protein coding genes. Mycologia 97:1034-1046

Liu X, Tian F, Zhang H-B, Pilarinou E, McLaughlin JL (1999) Biologically active blumenol A from the leaves of Annona glabra. Nat Prod Lett 14:77-81

Liu Y-J, Zhai C-Y, Liu Y, Zhang K-Q (2009) Nematicidal activity of Paecilomyces spp. and isolation of a novel active compound. J Microbiol 47:248-252

Liu J, Li F, Kim EL, Li JL, Hong J, Bae KS, Chung HY, Kim HS, Jung JH (2011) Antibacterial polyketides from the jellyfish-derived fungus Paecilomyces variotii. J Nat Prod 74:1826-1829

López-Llorca LV, Maciá-Vicente JG, Jansson J-B (2008) Mode of action and interactions of nematophagous fungi. In: Ciancio A, Mukerji $\mathrm{KG}$ (eds) Integrated management and biocontrol of vegetable and grain crop nematodes. Springer, Dordrecht, pp 51-76

Luangsa-ard J, Houbraken J, van Doorn T, Hong S-B, Borman AM, Hywel-Jones NL, Samson RA (2011) Purpureocillium, a new genus for the medically important Paecilomyces lilacinus. FEMS Microbiol Lett 321:141-149

Mao X-M, Zhan Z-J, Grayson MN, Tang M-C, Xu W, Li Y-Q, Yin W-B, Lin H-C, Chooi Y-H, Houk KN, Tang Y (2015) Efficient biosynthesis of fungal polyketides containing the dioxabicyclo-octane ring system. J Am Chem Soc 137:11904-11907

Martinez AF, Moraes LA (2015) Liquid chromatography-tandem mass spectrometry characterization of five new leucinostatins produced by Paecilomyces lilacinus CG-189. J Antibiot 68:178-184

Masuoka Y, Shin-ya K, Furihata K, Hayakawa Y, Seto H (1997) A novel substance with TGF- $\beta$ like activity, produced by a fungus, Diheterospora sp. J Antibiot 50:1058-1060

Masuoka Y, Shin-ya K, Kim Y-B, Yoshida M, Nagai K, Suzuki K-I, Hayakawa Y, Seto H (2000a) Diheteropeptin, a new substance with TGF- $\beta$ like activity, produced by a fungus, Diheterospora 
chlamydosporia. I. Production, isolation and biological activities. J Antibiot 53:788-792

Masuoka Y, Shin-ya K, Furihata K, Matsumoto H, Takebayashi Y, Nagai K, Suzuki K-I, Hayakawa Y, Seto H (2000b) Diheteropeptin, a new substance with TGF- $\beta$ like activity, produced by a fungus, Diheterospora chlamydosporia. II. Physico-chemical properties and structure elucidation. J Antibiot 53:793-798

Moosavi MR, Zare R (2012) Fungi as biological control agents of plantparasitic nematodes. In: Mérillon JM, Ramawat KG (eds) Plant defence: biological control. progress in biological control, vol 12., pp 67-107

Nakajima M, Itoi K, Takamatsu Y, Sato S, Furukawa Y, Furuya K, Honma T, Kadotani J, Kozasa M, Haneishi T (1991) Cornexistin: a new fungal metabolite with herbicidal activity. J Antibiot 44:1065-1072

Nicol JM, Turner SJ, Coyne DL, den Nijs L, Hockand S, Tahna Maafi Z (2011) Current nematode threats to world agriculture. In: Jones J, Gheysen G, Fenoll C (eds) Genomics and molecular genetics of plant-nematode interactions. Springer, Dordrecht, pp 21-43

Nigh AE, Thomason IJ, van Gudy SD (1980) Identification and distribution of fungal parasites of Heterodera schachtii eggs in California. Phytopathology 70:884-889

Niu X-M, Wang YL, Chu YS, Xue HX, Li N, Wei LX, Mo MH, Zhang KQ (2010) Nematodetoxic aurovertin-type metabolites from a rootknot nematode parasitic fungus Pochonia chlamydosporia. J Agric Food Chem 58:828-834

Nordbring-Hertz B, Jansson H-B, Tunlid A (2011) Nematophagous fungi. In: Encyclopedia of life sciences. John Wiley \& Sons, Chichester. doi:10.1002/9780470015902.a0000374.pub3

Park J-O, Hargreaves JR, McConville EJ, Stirling GR, Ghisalberti EL, Sivasithamparam K (2004) Production of leucinostatins and nematicidal activity of Australian isolates of Paecilomyces lilacinus (Thom) Samson. Lett Appl Microbiol 38:271-276

Perdomo H, Cano J, Gené J, García D, Hernández M, Guarro J (2013) Polyphasic analysis of Purpureocillium lilacinum isolates from different origins and proposal of the new species Purpureocillium lavendulum. Mycologia 105:151-161

Pfister DH (1997) Castor, pollux and life histories of fungi. Mycologia 89:1-23

Quandt CA, Kepler RM, Gams W, Evans HC, Hughes D, Humber R, Hywel-Jones N, Li Z, Luangsa-Ard JJ, Rehner SA, Sato H, Shrestha B, Sung G-H, Yao Y-J, Zare R, Spatafora JW (2014) Phylogeneticbased nomenclatural proposals for Ophiocordycipitaceae (Hypocreales) with new combinations in Tolypocladium. IMA Fungus 5:121-134

Römpp Online (2015) Version 4.0. Georg Thieme Verlag Suttgart. https:// roempp.thieme.de/roempp4.0/do/Welcome.do Accessed 14 July 2015

Rubner A (1996) Revision of predacious hyphomycetes in the DactylellaMonacrosporium complex. Stud Mycol 39:1-134

Scholler M, Hagedorn G, Rubner A (1999) A reevaluation of predatory orbiliaceous fungi. II. A new generic concept. Sydowia 51:89-113

Shinonaga H, Kawamura Y, Ikeda A, Aoki M, Sakai N, Fujimoto N, Kawashima A (2009a) The search for a hair-growth stimulant: new radicicol analogues as WNT-5A expression inhibitors from Pochonia chlamydosporia var. chlamydosporia. Tetrahedron Lett 50:108-110

Shinonaga H, Kawamura Y, Ikeda A, Aoki M, Sakai N, Fujimoto N, Kawashima A (2009b) Pochonins K-P: new radicicol analogues from Pochonia chlamydosporia var. chlamydosporia and their WNT-5A expression inhibitory activities. Tetrahedron 65:3446-3453

Shinonaga H, Sakai N, Nozawa Y, Ikeda A, Aoki M, Kawashima A (2009c) 13-Bromomonocillin, a new WNT-5A expression inhibitor produced by Pochonia chlamydosporia var. chlamydosporia. Heterocycles 78:2855-2861

Spatafora JW, Quandt AC, Kepler RM, Sung G-H, Shrestha B, HywelJones NL, Luangsa-ard JJ (2015) New 1F1N species combinations in Ophiocordycipitaceae (Hypocreales). IMA Fungus 6:357-362
Stadler M, Anke H, Sterner O (1993a) Linoleic acid, the nematicidal principle of nematophagous fungi. Arch Microbiol 160:401-405

Stadler M, Anke H, Sterner O (1993b) New biologically active compounds from the nematode-trapping fungus Arthrobotrys oligospora Fres. Z Naturforsch 48c:843-850

Stadler M, Mayer A, Anke H, Sterner O (1994) Fatty acids and other compounds with nematicidal activity from cultures of basidiomycetes. Planta Med 60:128-132

Stadler M, Tichy H-V, Katsiou E, Hellwig V (2003) Chemotaxonomy of Pochonia and other conidial fungi with Verticillium-like anamorphs. Mycol Prog 2:95-122

Summerbell RC, Gueidan C, Schroers H-J, de Hoog GS, Starink M, Rosete YA, Guarro J, Scott JA (2011) Acremonium phylogenetic overview and revision of Gliomastix, Sarocladium, and Trichothecium. Stud Mycol 68:139-162

Szwalbe AJ, Williams K, O'Flynn DE, Bailey AM, Mulholland NP, Vincent JL, Willis CL, Cox RJ, Simpson TJ (2015) Novel nonadride, heptadride and maleic acid metabolites from the byssochlamic acid producer Byssochlamys fulva IMI 40021 - an insight into the biosynthesis of maleidrides. Chem Commun (Cambr). 51:17088-17091

Usuki H, Toyo-oka M, Kanzaki H, Okuda T, Nitoda T (2009) Pochonicine, a polyhydroxylated pyrrolizidine alkaloid from fungus Pochonia suchlasporia var. suchlasporia TAMA 87 as a potent $\beta$ - $N$ acetylglucosaminidase inhibitor. Bioorg Med Chem 17:7248-7253

Wang Y-L, Li L-F, Li D-X, Wang B, Zhang K-Q, Niu X-M (2015) Yellow pigment aurovertins mediate interactions between the pathogenic fungus Pochonia chlamydosporia and its nematode host. J Agric Food Chem 63:6577-6587

Wei L-X, Zhang H-X, Tan J-L, Chu Y-S, Li N, Xue H-X, Wang Y-L, Niu X-M, Zhang Y, Zhang K-Q (2011) Arthrobotrisins A-C, oligosporons from the nematode-trapping fungus Arthrobotrys oligospora. J Nat Prod 74:1526-1530

Wesemael WML, Viaene N, Moens M (2011) Root-knot nematodes (Meloidogyne spp.) in Europe. Nematology 13:3-16

Wu D-K, Zhang C-P, Zhu C-Y, Wang Y-L, Guo L-L, Zhang K-Q, Niu XM (2013) Metabolites from carnivorous fungus Arthrobotrys entomopaga and their functional roles in fungal predatory ability. $\mathrm{J}$ Agric Food Chem 61:4108-4113

Xu Z-F, Wang B-L, Sun H-K, Yan N, Zeng Z-J, Zhang K-Q, Niu X-M (2015) High trap formation and low metaboliteproduction by disruption of the polyketide synthase gene involved in the biosynthesis of arthrosporols from the nematode-trapping fungus Arthrobotrys oligospora. J Agric Food Chem 63:9076-9082

Yang J, Zhang K-Q (2014) Biological control of plant-parasitic nematodes by nematophagous fungi. In: Zhang K-Q, Hyde KD (eds) Nematode-trapping fungi. Springer, Dordrecht, pp 231-262

Yang Y, Yang E, An Z, Liu Y (2007) Evolution of nematode-trapping cells of predatory fungi of the Orbiliaceae based on evidence from rRNA-encoding DNA and multiprotein sequences. Proc Natl Acad Sci U S A 104:8379-8384

Yang E, Xu L, Yang Y, Zhang X, Xiang M, Wang C, An Z, Liu X (2012) Origin and evolution of carnivorism in the Ascomycota (fungi). Proc Natl Acad Sci U S A 109:10960-10965

Yu Z-F, Mo M-H, Zhang Y, Zhang K-Q (2014) Taxonomy of nematodetrapping fungi from Orbiliaceae, Ascomycota. In: Zhang K-Q, Hyde KD (eds) Nematode-trapping fungi. Springer, Dordrecht, pp 41-209

Zhang H-X, Tan J-L, Wei L-X, Wang Y-L, Zhang C-P, Wu D-K, Zhu C-Y, Zhang Y, Zhang K-Q, Niu X-M (2012) Morphology regulatory metabolites from Arthrobotrys oligospora. J Nat Prod 75:1419-1429

Zhu J-S, Nakagawa S, Chen W, Adachi I, Jia Y-M, Hu X-G, Fleet GWJ, Wilson FX, Nitoda T, Horne G, van Well R, Kato A, Yu C-Y (2013) Synthesis of eight stereoisomers of pochonicine: nanomolar inhibition of $\beta$ - $N$-acetylhexosaminidases. J Org Chem 78:10298-10309 